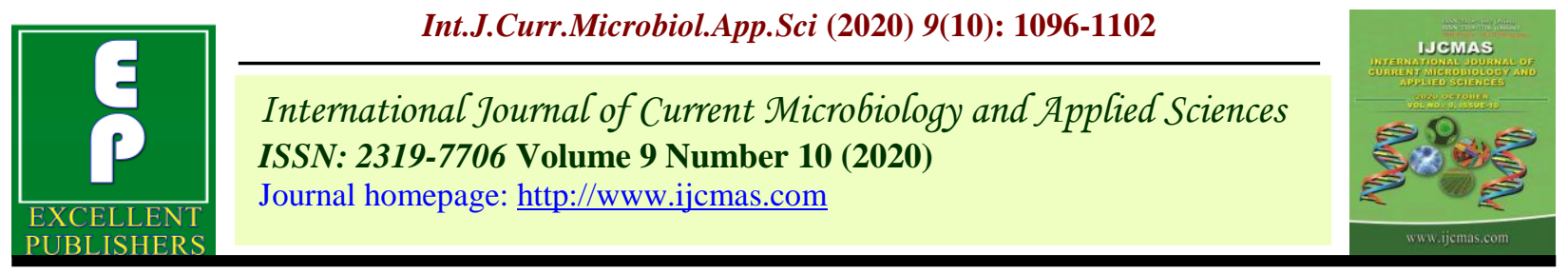

Original Research Article

https://doi.org/10.20546/ijcmas.2020.910.131

\title{
Response of Promising Midlate Maturing Sugarcane Varieties to Different Doses of Nitrogen Fertilizer
}

\author{
N.V. Sarala*, M. Hemanth Kumar B. Vajantha and T.M. Hemalatha \\ Acharya N.G.Ranga Agricultural University, Agricultural Research Station, Perumallapalle - \\ 517505, Chittoor (dt) Andhra Pradesh, India \\ *Corresponding author
}

Keywords

Sugarcane,

Nitrogen levels,

Cane yield and

Juice quality

Article Info

Accepted:

10 September 2020

Available Online:

10 October 2020

\section{A B S T R A C T}

Field trail was conducted at Agricultural Research Station, Perumallapalle in two plant crops to evaluate the response of mid late maturing sugarcane varieties to different doses of nitrogen fertilizer. Four midlate varieties viz., 2012T58, 2012T72, 2012T78 and 2012T182 were tested at four nitrogen levels i.e., $100 \%, 125 \%, 150 \%$ and $175 \%$ of recommended dose of nitrogen (RDN: $224 \mathrm{~kg} / \mathrm{ha}$ ). Application of nitrogen @ 150\% RDN produced significantly higher values for millables canes, cane yield and per cent sucrose. Hence application of nitrogen @ $336 \mathrm{~kg} / \mathrm{ha}$ is the viable fertilizer nitrogen for midlate varieties of sugarcane crop in sandy loam soils of southern agro-climatic zone of Andhra Pradesh. However, the effect of nitrogen levels on juice quality parameters was not significant. Among the sugarcane midlate varieties, 2012T58 and 2012T 182 responded well to the applied nitrogen and recorded higher cane yield.

\section{Introduction}

Most of the southern zone of Andhra Pradesh, where sugarcane is grown, low in soil nitrogen, this coupled with long term mono cropping as a consequences of raising several ratoons year after year and land scarcity justifies continued use of nitrogen fertilizer in field. However, nitrogen fertilizer is costly and indiscriminate management such as inappropriate rate, time and placement may lead to poor crop performance and yield; besides, it may result in such losses as nitrate due to leaching, denitrification and ammonium voltalization with serious environmental pollution. Nitrogen is the primary nutrient which influences the yield and quality of cane. Earlier Saldarsringa et al., (1998) reported $\mathrm{N}$ fertilizer rate as one of the most influencing factors on cane yields and response to applied nitrogen is universal, nitrogen increases the source of capacity, namely leaf area index, leaf area duration, early closure and rate of photosyntehsis 
(Hunsigi,1993). An increased sugarcane yield with nitrogen application is attributed to the increased number of tillers and yield attributes like stalk length, stalk diameter and number of millable canes (Abayomi, 1987). Different sugarcane varieties have different yield potential and their specific attributes (Tayade et al., 2016). Considerable differences in the response of sugarcane varieties to applied nitrogen was reported from Tamilnadu (Srinivasan, 1995), Andhra Pradesh (Nagamadhuri et al., 2011 and Sarala et al., 2015). The new varieties developed have improved cane and sugar yields, resistance to pests and diseases, good milling qualities and adaptability to local growing conditions. The varieties show differential response as per the potential when cultivated in the recommended agro expected to yield as per the potential when cultivated in the recommended agro-ecological zones and applying appropriate agronomic practices. (Ramesh et al., 1996), and declining soil fertility as result of depletion of the essential plant nutrients viz., N,P and $\mathrm{K}$ (Bell et al.,2001; Gerside and Bell,2009 and Vajantha et.al.,2017). Hence this study was under taken to determine the optimum nitrogen fertilizer rate for increased and sustained cane and sugar yields and to select a high fertilizer use efficient midlate variety suitable for the southern zone of A.P.

\section{Materials and Methods}

Field experiment was conducted at Agricultural Research Station, Perumallapalle, Andhra Pradesh, during 2018-19 and 2019-20. The soils of the experimental are sandy loam in texture, Neutral in $\mathrm{P}^{\mathrm{H}}$, normal in EC, low in available nitrogen, medium in available phosphorus and high in available potassium. The experiment was designed in split plot with three replications, varieties as main plots and nitrogen levels as subplots, four promising midlate maturing varieties viz., 2012T58, 2012T 72,2012T78 and 2012 T182 were tested with four levels of nitrogen viz., $100 \%$, $125 \%, 150 \%$ and $175 \%$ of recommended dose of nitrogen (RDN : $224 \mathrm{~kg} / \mathrm{ha}$ ). Nitrogen was applied in the form of urea and applied in two equal splits at 45 and 90 days after planting as per treatments. Phosphorus and potassium were applied @ $112 \mathrm{~kg} / \mathrm{ha}$ in the form of SSP and MOP, respectively. Furrows were made at spacing of $90 \mathrm{~cm}$ and three budded setts @ 40,000/ha were planted in the first fortnight of January during both years of study. Atrazine @ $2 \mathrm{~kg}$ a.i/ha was sprayed as pre emergence on the $3^{\text {rd }}$ day after planting of setts. Irrigations were provided as and when necessary. All other agronomic practices like hand weeding, earthing up, trash twist propping etc. were carried out according to recommendations. Observations in both plant crops were recorded on germination count, millable cane length, number of millable canes, cane girth, single cane weight and cane yield. Cane juice of different treatments was analysed for quality at harvest. Brix was recorded by using hydrometer and Pol\% was recorded by polarimeter and sucrose was estimated by using standard procedures (Spencer and Medae, 1945).

\section{Results and Discussion}

Germination count recorded in both the plant crops at 30 days after planting differed significantly with sugarcane varieties where as non significant effect of graded level of nitrogen application was noticed on germination. The yield and yield parameters were recorded at the time of harvest. Among midlate varieties, 2012T58 and 2012T182 recorded higher per cent of germination. Mean cane length and cane diameter were not significantly influenced by the sugarcane varieties, but significant differences for single cane weight was observed in varieties, Among the different midlate varieties, 
2012T58 registered significantly higher cane weight than other varieties. The differences in single cane weight, cane length and cane thickness could be attributed to the inherent differential phenotypic make up of the sugarcane varieties. Significant variations for yield attributing characters among the sugarcane varieties were also reported by the earlier by Bharathalakshmi et al., (2003). The lengthier and thick canes were produced when nitrogen was applied @ $150 \%$ RDN. The results are in accordance with Nagamadhuri et al., (2011) and Sarala et al., (2015). During both the years of study number of millable canes /ha was influenced by the varieties and graded levels of nitrogen doses. Among the varieties the sugarcane midlate maturing variety 2012 T58 registered higher number of millable canes/ha. than the other three sugarcane varieties. These results were in conformity with the result of Bell and Garside (2001) who reported substantial cultivar differences for number of millable cane. The number of millable canes is a major constituent of cane yield which provides the plant with optimum number of stalks needed for good yield is known to be dependent on the availability of various nutrients. Cane yield was influenced significantly by sugarcane varieties and nitrogen levels. During both the years of study higher cane yield was recorded by the variety 2012 T58, followed by $2012 \mathrm{~T} 182$.

Highest shoot population coupled with efficient conversion of tillers in to millable canes at harvest in these varieties could have contributed to higher cane yield. Similar results were reported by Srinivas et al., (2003) and Tayade (2018). A significant progressive increase in cane yield was observed with increase in the dose of nitrogen from $100 \%$ RDN to $150 \%$ RDN. Midlate sugarcane varieties responded linearly up to $150 \%$ RDN (336 kg N /ha). Rakkiyappan (1981) and Thakur et a., (1991) also had reported the differential response of sugarcane varieties to varied levels of nitrogen application.Juice extracted from cane assumes greater importance as it is directly related to the commercial output of sugarcane. The brix values, sucrose content and purity per centage determine the quality of cane. In the present investigation brix (\%), sucrose content $(\%)$, purity (\%) and CCS (\%) estimated at harvest differed significantly due to different sugarcane varieties. The sugarcane midlate variety $2012 \mathrm{~T} 58$ recorded maximum brix (\%), sucrose (\%), CCS(\%) and purity (\%) followed by 2012 T72 than other midalte maturing varieties. The juice qualities are mainly determined by the genetic makeup of the varieties this is in accordance with findings of Garside and Bell (2009).The quality parameters viz., brix (\%), sucrose (\%),CCS $(\%)$ and purity (\%) were not affected by increasing nitrogen application. This could be due to early application of nitrogen .Thus the detrimental effect of higher nitrogen on juice quality was minimized before the maturity age of the cane (Gana et al., 2007). Higher quantity of nitrogen fertilizer generally results in sugars. But as the crop ages and matures, it is expected that nitrogen content will be reduced and there is an increasing conversion of reducing sugars to sucrose (Hussian et al., 1990). During both the years of study interaction effect between yield and yield parameters of sugarcane varieties and nitrogen levels were non -.significant.

It is concluded, among the promising sugarcane midlate varieties, 2012T 58 and 2012 T 182 responded well to the applied nitrogen and recorded higher cane yield. Application of nitrogen@ $336 \mathrm{~kg} / \mathrm{ha}$ is the viable fertilizer nitrogen for promising midlate maturing varieties of sugarcane in sandy loam soils of southern agro climatic zone of Andhra Pradesh to realize higher cane yield (Table 1 and 2). 
Table.1 Effect of nitrogen application on germination $(\%)$ and yield attributing parameters of promising midlate maturing sugarcane varieties

\begin{tabular}{|c|c|c|c|c|c|c|c|c|c|c|c|c|c|c|c|c|c|}
\hline \multirow[t]{2}{*}{ Treatment } & \multicolumn{2}{|c|}{$\begin{array}{c}\text { Germination } \\
\text { per cent at } 45 \\
\text { DAP }\end{array}$} & \multicolumn{3}{|c|}{$\begin{array}{l}\text { Millable cane } \\
\text { length }(\mathbf{m})\end{array}$} & \multicolumn{3}{|c|}{$\begin{array}{l}\text { Millable cane } \\
\text { girth }(\mathbf{c m})\end{array}$} & \multicolumn{3}{|c|}{$\begin{array}{c}\text { Single cane weight } \\
(\mathrm{kg})\end{array}$} & \multicolumn{3}{|c|}{$\begin{array}{l}\text { Number of millable } \\
\text { canes/ha }\end{array}$} & \multicolumn{3}{|c|}{$\begin{array}{l}\text { Cane yield } \\
\text { (t/ha) }\end{array}$} \\
\hline & $\begin{array}{c}\text { I } \\
\text { plant } \\
\text { crop }\end{array}$ & $\begin{array}{c}\text { II } \\
\text { plant } \\
\text { crop }\end{array}$ & $\begin{array}{c}\text { I } \\
\text { plant } \\
\text { crop }\end{array}$ & $\begin{array}{l}\text { II plant } \\
\text { crop }\end{array}$ & Mean & $\begin{array}{l}\text { I plant I } \\
\text { crop }\end{array}$ & $\begin{array}{l}\text { II plant } \\
\text { crop }\end{array}$ & Mean & $\begin{array}{l}\text { I plant } \\
\text { crop }\end{array}$ & $\begin{array}{l}\text { II plant } \\
\text { crop }\end{array}$ & Mean & $\begin{array}{l}\text { I plant } \\
\text { crop }\end{array}$ & $\begin{array}{c}\text { II } \\
\text { plant } \\
\text { crop }\end{array}$ & Mean & $\begin{array}{l}\text { I } \\
\text { plant } \\
\text { crop }\end{array}$ & $\begin{array}{c}\text { II } \\
\text { plant } \\
\text { crop }\end{array}$ & Mean \\
\hline \multicolumn{18}{|c|}{ Sugarcane promising midlate maturing Varieties } \\
\hline $2012 T 58$ & 73.9 & 75.5 & 2.82 & 2.52 & 2.67 & 2.80 & 2.68 & 2.74 & 1.47 & 1.54 & 1.50 & 78569 & 87923 & 83246 & 104.5 & 112.0 & 108.2 \\
\hline $2012 T 72$ & 68.4 & 65.6 & 2.79 & 2.50 & 2.64 & 2.66 & 2.45 & 2.55 & 1.28 & 1.37 & 1.32 & 76318 & 84362 & 80340 & 86.0 & 106.6 & 96.3 \\
\hline $2012 T 78$ & 68.9 & 68.7 & 2.72 & 2.47 & 2.59 & 2.82 & 2.52 & 2.67 & 1.32 & 1.35 & 1.35 & 67009 & 86897 & 76953 & 80.9 & 107.8 & 94.3 \\
\hline 2012T182 & 72.5 & 69.3 & 2.80 & 2.41 & 2.60 & 2.86 & 2.53 & 2.65 & 1.35 & 1.38 & 1.36 & 68194 & 80972 & 74583 & 95.8 & 108.6 & 102.2 \\
\hline SEm+/- & 1.94 & 0.78 & 0.01 & 0.05 & -- & 0.05 & 0.02 & -- & 0.02 & 0.03 & -- & 329 & 403.4 & - & 0.69 & 0.43 & -- \\
\hline CD (0.05) & 2.96 & 3.52 & NS & NS & -- & NS & NS & -- & 0.10 & 0.13 & -- & 1471 & 1803.2 & - & 3.12 & 1.94 & -- \\
\hline \multicolumn{18}{|c|}{ Nitrogen doses } \\
\hline $100 \% \mathrm{RDN}$ & 70.5 & 68.5 & 2.64 & 2.36 & 2.50 & 2.63 & 2.33 & 2.48 & 1.38 & 1.32 & 1.35 & 69016 & 77686 & 73351 & 81.9 & 95.2 & 88.5 \\
\hline $125 \% \mathrm{RDN}$ & 71.0 & 67.7 & 2.84 & 2.48 & 2.66 & 2.77 & 2.46 & 2.61 & 1.39 & 1.36 & 1.37 & 69234 & 84507 & 76870 & 91.4 & 107.4 & 99.4 \\
\hline $150 \%$ RDN & 71.3 & 69.6 & 2.92 & 2.54 & 2.73 & 2.92 & 2.48 & 2.70 & 1.42 & 1.45 & 1.43 & 77318 & 90787 & 84052 & 99.3 & 119.0 & 109.1 \\
\hline $175 \%$ RDN & 71.2 & 66.2 & 2.70 & 2.52 & 2.61 & 2.64 & 2.42 & 2.53 & 1.45 & 1.40 & 1.42 & 72541 & 87175 & 79858 & 93.0 & 112.0 & 102.5 \\
\hline SEm+/- & 0.36 & 0.60 & 0.03 & 0.03 & -- & 0.02 & 0.02 & -- & 0.016 & 0.019 & -- & 981 & 950.2 & -- & 0.39 & 1.05 & \\
\hline CD (0.05) & NS & NS & 0.10 & 0.01 & -- & 0.07 & 0.09 & -- & NS & NS & -- & 318 & 2928 & -- & 1.22 & 3.26 & \\
\hline $\begin{array}{c}\text { Varieties at } \\
\text { Nitrogen } \\
\text { doses }\end{array}$ & NS & NS & NS & NS & -- & NS & NS & & NS & NS & -- & NS & NS & -- & NS & 6.67 & \\
\hline $\begin{array}{c}\text { Nitrogen } \\
\text { doses at } \\
\text { varieties }\end{array}$ & NS & NS & NS & NS & & NS & NS & & NS & NS & -- & NS & NS & -- & NS & 5.94 & \\
\hline
\end{tabular}


Table.2 Effect of nitrogen application on quality parameters of promising midlate maturing sugarcane varieties

\begin{tabular}{|c|c|c|c|c|c|c|c|c|c|c|c|c|}
\hline \multirow[t]{2}{*}{ Treatment } & \multicolumn{2}{|c|}{ Brix (\%) } & \multirow[b]{2}{*}{ Mean } & \multicolumn{3}{|c|}{ Sucrose (\%) } & \multicolumn{3}{|c|}{$\operatorname{CCS}(\%)$} & \multicolumn{3}{|c|}{ Purity (\%) } \\
\hline & $\begin{array}{l}\text { I plant } \\
\text { crop }\end{array}$ & $\begin{array}{l}\text { II plant } \\
\text { crop }\end{array}$ & & $\begin{array}{l}\text { I plant } \\
\text { crop }\end{array}$ & $\begin{array}{l}\text { II plant } \\
\text { crop }\end{array}$ & Mean & $\begin{array}{l}\text { I plant } \\
\text { crop }\end{array}$ & $\begin{array}{l}\text { II plant } \\
\text { crop }\end{array}$ & Mean & $\begin{array}{l}\text { I plant } \\
\text { crop }\end{array}$ & $\begin{array}{l}\text { II plant } \\
\text { crop }\end{array}$ & Mean \\
\hline $2012 T 58$ & 21.03 & 20.95 & 20.99 & 19.60 & 19.92 & 19.76 & 13.66 & 13.17 & 13.14 & 95.56 & 95.40 & 95.48 \\
\hline 2012T72 & 20.39 & 20.36 & 20.37 & 19.15 & 19.24 & 19.19 & 12.97 & 12.93 & 12.92 & 93.42 & 92.25 & 92.83 \\
\hline $2012 T 78$ & 19.67 & 19.82 & 19.74 & 18.99 & 19.02 & 19.00 & 12.79 & 12.87 & 12.83 & 92.56 & 93.00 & 92.78 \\
\hline 2012T182 & 19.89 & 19.76 & 19.82 & 19.10 & 19.13 & 19.11 & 12.82 & 12.75 & 12.78 & 92.74 & 92.45 & 92.61 \\
\hline SEm+/- & 0.09 & 0.10 & -- & 0.076 & 0.03 & -- & 0.07 & 0.03 & -- & 0.52 & 0.48 & -- \\
\hline CD (0.05) & 0.44 & 0.47 & -- & 0.34 & 0.14 & -- & 0.35 & 0.16 & -- & 2.32 & 2.18 & -- \\
\hline \multicolumn{13}{|l|}{ Nitrogen doses } \\
\hline $100 \%$ RDN & 20.34 & 20.40 & 20.37 & 19.25 & 19.18 & 19.21 & 12.87 & 12.84 & 12.85 & 93.32 & 93.02 & 93.17 \\
\hline $125 \%$ RDN & 20.44 & 20.45 & 20.44 & 19.15 & 19.03 & 19.09 & 12.92 & 12.79 & 12.85 & 93.93 & 92.75 & 93.34 \\
\hline $150 \%$ RDN & 20.22 & 20.20 & 20.21 & 19.04 & 19.10 & 19.07 & 12.99 & 12.92 & 12.95 & 93.19 & 93.45 & 93.32 \\
\hline $175 \% \mathrm{RDN}$ & 20.10 & 20.01 & 20.05 & 19.18 & 19.13 & 19.15 & 12.87 & 12.98 & 12.92 & 92.68 & 93.24 & 92.96 \\
\hline SEm+/- & 0.13 & 0.11 & -- & 0.11 & 0.04 & -- & 0.05 & 0.03 & -- & 0.66 & 0.35 & -- \\
\hline CD (0.05) & NS & NS & & NS & NS & -- & NS & NS & -- & NS & NS & -- \\
\hline $\begin{array}{l}\text { Varieties at } \\
\text { Nitrogen doses }\end{array}$ & NS & NS & & NS & NS & -- & NS & NS & -- & NS & NS & -- \\
\hline $\begin{array}{l}\text { Nitrogen doses } \\
\text { at varieties }\end{array}$ & NS & NS & & NS & NS & -- & NS & NS & -- & NS & NS & -- \\
\hline
\end{tabular}




\section{References}

Abayomi, A.Y. 1987. Growth, yield and crop quality performance of sugarcane cultivar Co 957 under different rates of nitrogen and potassium application fertilizers. Journal of Agricultural Sciences (Cambridge) 109: 285-295.

Bell, M.J. Garside, A.L. Haplin, N.V. and Bertheisen.J.E.2001.Yield response to breaking the sugarcane monoculture. Proceedings of $10^{\text {th }}$ Australian Society of Agronomy conference. January. 2001. Hobart Tasamania.

Bharathalakshmi M., Chitkala Devi T, Narasima Rao IV, Rao K.L. (2003). Effect of time of nitrogen application on yield and quality of early maturing sugarcane varieties under rainfed conditions. Sugar Tech 5(1\&2): 73-76.

Garside, A.L. and M.J. Bell. 2009. Row spacing and planting density effects on the growth and yield of sugarcane. Crop and Pasture 60:555-565.

Hunsigi, G. 1993. Production of sugarcane theory and practice. Berlin: SpringerVerlag.

Hussian, I., Atta, M and Nazir M.S. 1990. Effect of NPK fertilizer application on the growth, yield and quality of autumn planted sugarcane. Pakistan Sugar Journal. 591): 1-53.

Naga Madhuri, K.V., M. Hemanth Kuar, and N.V. Sarala, 2011. Influence of higher doses of nitrogen on yield and quality of early maturing sugarcane varieties. Sugar Tech 13(1): 96-98.

Rakkiyappan, P. 1991. Time of application of nitrogen. Annual Report, Sugarcane Breeding Institute, 1990-91, p: 48.

Ramesh, P and M. Mahadevaswamy. 1996. Agronomic practices for some promising sugarcane varieties in tropical India. Indian sugar 46:719-722.

Sarala N.V. Sabitha N., Subba Rao. M., Hemanth Kumar M., Vajantha B. and
Giridhar V. 2015. Response of prerelease early maturing sugarcane varieties to different levels of nitrogen fertilizer. Andhra Pradesh. Journal of Agricultural Science (2): 78-81.

Saldarringa, A.S. Angulo, A.E. Soto, R.E. and A. Leyva, 1998. Proc. Inter Amrican Sugarcane Sminar, Crop Production and Mechnization, Miami, Florida. 9-11, September. Pp. 208-225.

Spencer, G.L. and Meade, G.P. 1963. Cane Sugar hand book, ${ }^{\text {th }}$ Ed.GP Meade, John Wiley and Sons. Inc. New York.

Sukla, S.K. 2007. Productivity and economics of high-sugar genotypes of sugarcane (Accharum officinarum hybrid complex) in plant-ratoon system under various planting season and fertility levels. Indian Journal of Agronomy 52: 164-167.

Srinivasan, T.R. 1995. Crop production technologies . In Sugarcane production manual, ed. K.C. Alexander and S. Srulraj, 26-42. Coimbatore: Sugarcane Breeding Institute.

Srinivas, D., Rao, B.R.B., Suresh, M., Vijayakumar, B and Krishna Reddy, L. 2003 Influence of levels of nitrogen on the yield and quality of early maturing sugarcane varieties .Co-operative Sugar, 34 (6): 479-482.

Thakur R., Jain R.C., Sharma S.R., Thakur G.L., Nema D.P. (1991). Response of promising early, mid-late and late varieties of sugarcane of the region to nitrogen application. Bharatiya Sugar 61(10): 1125.

Tayade A.S. Bhaskaran A. (2016). Effect of nitrogen application on growth, yield and juice quality of promising sugarcane genotypes. In: International Conference \& Exhibition on Sugarcane Value Chain - Vision 2025. Pune, India: 53.

Tayade A.S., Geetha P., Dhanapal R., Hari K. (2016). Effect of in-situ trash 
management on sugarcane under wide row planting system. Journal of Sugarcane Research 6 (1): 35-41.

Vajantha B., Sarala N.V., Subba Rao M., Hemanth Kumar M. and Hemalatha
T.M. 2017. Nitrogen uptake, Nitrogen were efficiency and yield of sugarcane varieties as influenced by levels of nitrogen fertilizers. Trends in Biosciences 10 (26).

\section{How to cite this article:}

Sarala, N.V., M. Hemanth Kumar B. Vajantha and Hemalatha, T.M. 2020. Response of Promising Midlate Maturing Sugarcane Varieties to Different Doses of Nitrogen Fertilizer. Int.J.Curr.Microbiol.App.Sci. 9(10): 1096-1102. doi: https://doi.org/10.20546/ijcmas.2020.910.131 